\title{
Pastoral da Juventude do Meio Popular e Puebla: análise histórica da recepção das "opções preferenciais pelos jovens e pelos pobres"1
}

\author{
Youth Pastoral of the Popular \\ Environment and Puebla: \\ an Historical analysis of the "preferential options for \\ the young people and for the poor" reception
}

Wellington Teodoro da Silva Daniel Rocha

\section{Resumo}

Este artigo apresenta resultados de pesquisa sobre jovens católicos organizados na Pastoral da Juventude do Meio Popular - PJMP. Trata-se de uma pastoral marcada pela condição militante de seus membros inserida na tradição da esquerda católica brasileira que surgiu a partir da primeira metade da década de 1960. Descobrimos que essa pastoral foi marcada de modo notável pela Conferência de Puebla, ocorrida no ano de 1979. Apresentamos a recepção do texto final dessa Conferência por esses jovens no âmbito da opção preferencial pelos jovens e da opção preferencial pelos pobres. Nossa pesquisa cobriu o período compreendido entre meados da década de 1980 e 1990 em Minas Gerais.

\footnotetext{
${ }^{1}$ Este artigo apresenta resultados parciais da pesquisa "Juventude, Religião e Política" financiada pela Fundação de Amparo à Pesquisa do Estado de Minas Gerais - FAPEMIG.
} 
Palavras-chave: Juventude. Religião e política. Esquerda católica.

\begin{abstract}
This article presents research results on young Catholics organized in the Youth Pastoral of the Popular Environment - PJMP. It is a pastoral marked by the militant condition of its members, inserted in the tradition of the Brazilian Catholic Left that arose from the first half of the 1960s. We found that this pastoral care was marked in a remarkable way by the Puebla Conference, which took place in the year of 1979. We present the reception of the final text of this Conference by these young people in the context of the preferential option for young people and the preferential option for the poor. Our research covered the period between the mid-1980s and 1990s in Minas Gerais.
\end{abstract}

Keywords: Youth. Religion and politics. Catholic left.

May you always be courageous

Stand upright and be strong And may you stay

Forever young

Bob Dylan

\title{
Introdução
}

Compreendemos a juventude como um tema aberto por definição. Não é possivel esgotá-lo em uma única categoria interpretativa ou em uma definição precisa e inquestionável. Como diria Reinhart Koselleck, um conceito, "para poder ser um conceito, deve manter-se polissêmico. Embora o conceito esteja associado à palavra, ele é mais do que uma palavra". ${ }^{2}$ Pensamos que acontece o mesmo que a liberdade na poesia de Cecília Meireles: ${ }^{3}$ quando falamos juventude sabemos bem do que se trata, mas quando perguntamos o que é ser jovem, a formulação de uma definição precisa e universalmente

\footnotetext{
${ }^{2}$ KOSELLECK, R., Futuro passado, p. 109.

${ }^{3}$ MEIRELES, C., Poesias completas.
} 
aceita parece ser uma impossibilidade. O "ser jovem" é relativo segundo o momento histórico, o ambiente sociocultural e econômico, o movimento das mentalidades etc. O desenvolvimento fisiológico e a idade cronológica são importantes, mas insuficientes para definir o conceito de juventude e a experiência de ser jovem.

A partir dos lugares teóricos das Ciências da Religião e da História, este artigo parte da percepção de que a juventude pode ser caracterizada como um momento existencial marcado pela liminaridade e pelo transitório. Situa-se entre a dependência da infância e a autonomia da idade adulta. É um momento em que o futuro povoa a consciência mais que nos demais momentos da vida. Nos momentos anteriores, infância e adolescência, a consciência é, sobretudo, habitada pelas descobertas marcadas pelo tempo presente na formação do nomos, ou seja, das tessituras de sentidos do estar no mundo agora. Na idade adulta, o futuro cede espaço para o passado. No tempo presente do adulto, acontece a dialética entre o passado que ele já acumulou e o futuro já não tão largo e aberto como o jovem. O idoso por sua vez é pleno de passado. Sua consciência é tomada pela memória mais do que pela abertura ao futuro que lhe é breve. Arriscaríamos dizer que o adulto se apoia, primordialmente, na experiência, enquanto o jovem é guiado por suas expectativas.

A abertura e a condição de trânsito na direção do futuro fizeram a juventude ser compreendida no século XX como a presença do devir no presente e, portanto, como a força dinâmica da sociedade e da cultura. $\mathrm{O}$ apoio dos jovens passou a ser disputado pelos grandes movimentos, pelos projetos de nação e pelas lideranças políticas. Buscou-se organizar a participação dos jovens no mundo político/social através das juventudes comunistas, nazistas, socialistas, liberais etc. Os jovens se constituíram nos fiadores da força e legitimidade de projetos políticos, culturais e/ou nacionais. O regime moderno de historicidade, ${ }^{4}$ que tem sua origem no otimismo iluminista e na crença no progresso ilimitado da humanidade, fez com que os homens se orientassem pela luz que vinha do futuro. Um futuro pleno de realizações a ser construído pelo ilimitado conhecimento humano que estaria, agora, liberado das amarras

${ }^{4}$ Utilizamos aqui a concepção de regime de historicidade conforme a concebe o historiador François Hartog. De acordo com o autor, "regime de historicidade [...] podia ser compreendido de dois modos. Em uma acepção restrita, como uma sociedade trata seu passado e trata do seu passado. Em uma acepção mais ampla, regime de historicidade serviria para designar a modalidade de consciência de si de uma comunidade humana" (HARTOG, F., Regimes de historicidade, p. 28). E essa consciência de si tem a ver com a relação que uma determinada sociedade, ou parte dela, estabelece com passado, presente e futuro em diferentes épocas. 
do obscurantismo que caracterizava o passado, pronto para construir um mundo de riqueza e felicidade sem limites, o "Milênio secular". A herança de tal discurso no século XX - a crença no progresso e de que o presente seria sempre qualitativamente inferior ao futuro - acabou por encontrar nos jovens o motor de transformação da história, os inauguradores de uma nova época.

A Igreja Católica também se preocupou com esses atores e, em sintonia com o "espírito do tempo", abriu espaço e estimulou o surgimento de uma série de movimentos específicos de juventude da Ação Católica, a saber: Juventude Agrária Católica - JAC; Juventude Estudantil Católica - JEC; Juventude Independente Católica - JIC; Juventude Operária Católica - JOC e Juventude Universitária Católica - JUC.

Os jovens que estudamos neste artigo são militantes da Pastoral da Juventude do Meio Popular - PJMP. Ela é uma organização católica que surgiu em 1978 a partir da experiência de ex-membros da JOC após sua desestruturação no período da Ditadura Militar encerrado em 1985. A condição militante é estruturante da espiritualidade desses jovens e é herança, por um lado, do catolicismo engajado dos movimentos da Ação Católica. Por outro lado, eles sofreram a influência dos movimentos sociais e políticos diversos que ocorreram no país a partir da segunda metade da década de 1970 e, também, da hegemonia da Teologia da Libertação. Dentre os movimentos desse período destacamos as oposições sindicais; a fundação do Partido dos Trabalhadores; os movimentos de bairros e pelas eleições diretas.

\section{Catolicismo, política e transformação social no Brasil}

Paul Veyne ${ }^{5}$ desenvolveu uma importante reflexão a respeito da "novidade" apresentada pelo cristianismo que o tornou capaz de se tornar uma opção religiosa atrativa para uma parcela crescente dos cidadãos romanos. $\mathrm{O}$ autor entende que a promessa da ressurreição não foi o grande argumento. As demais religiões também possuíam discursos plausíveis sobre a morte e sua superação. Os cristãos não apresentaram um discurso mais ou menos razoável sobre os fins últimos ou o destino final do ser humano diante do máximo problema existencial da morte. Os cristãos convertidos foram seduzidos pelo dado do Filho de Deus ter vivido na história. Isso faz o próprio Deus participar das tramas e destinos da humanidade que, por sua vez, participa das tramas

\footnotetext{
${ }^{5}$ VEYNE, P., Quando nosso mundo se tornou cristão.
} 
divinas. Desse modo, a condição humana torna-se uma epopeia em fusão com o Transcendente, o Sagrado, o Absoluto. A condição histórica do ser humano ganha maior dramaticidade para o cristão que crê que as questões salvíficas, últimas, começam antes de sua morte. Desse modo, é criado e convidado a co-criar; participar do ato divino da criação.

Não sendo o paraíso distante, fora do tempo, que seduz e sim o drama absoluto da epopeia humana, o cristianismo retira dos grandes heróis o monopólio da história. Ela está disponível para cada pessoa anônima participar porque a expectativa da construção do Reino de Deus na terra acaba por engajar os cristãos na "obra de Deus" - "obra" que vai muito além do proselitismo e dos ritos religiosos. Vários cristãos nutriam profunda expectativa pelo dia em que sacerdotes de Deus e de Cristo "com ele reinarão durante mil anos" (Ap 20,6). A ação dos cristãos neste mundo seria uma condição essencial para a "vinda do Reino".

A esperança milenarista pode ser realizada historicamente, porque apenas ela é esperança de um futuro intra-histórico. Somente o milenarismo torna possível conceber o reino de Deus teleológica e não apocalipticamente e não mais encará-lo como fim catastrófico deste mundo, e sim como um ideal moral e político do qual os seres humanos podem aproximar-se por intermédio do trabalho incansável em si mesmos e no mundo. Somente o quiliasmo transforma a escatologia em teleologia ${ }^{6}$

Essa característica do cristianismo faz a igreja cristã ser uma religião política, ou, no mínimo, uma religião de incontornável politicidade. Passando ao caso brasileiro, no período monárquico, o catolicismo chegou a se constituir em religião civil, segundo Thales de Azevedo, ${ }^{7}$ por emprestar seus símbolos para a organização e legitimação do Estado e da nação. Ao mesmo tempo, ele se mantém uma instituição religiosa por ter no seu "núcleo duro" o anúncio da salvação e do final dos tempos. Existe voltada para o momento escatológico.

Após o término do Padroado, a Igreja Católica no Brasil organizou a sua estrutura voltando-se para Roma chamando seus fiéis à ordem. Posiciona-se diante do Estado convencendo-o que a mentalidade do brasileiro é católica e, portanto, ela seria a mediadora natural entre a mentalidade da nação e o poder político civil. Ela se autocompreende

\footnotetext{
${ }^{6}$ MOLTMANN, J., A vinda de Deus, p. 207.

${ }^{7}$ AZEVEDO, T., A religião Civil Brasileira.
} 
como militante e tem por objetivo organizar um corpo disciplinado de fiéis e clero sob o comando da hierarquia.

Até meados do século XX, a Igreja utilizou seu prestígio e sua ascendência sobre a consciência moral e o imaginário religioso da população como "moeda" para negociar com o Estado e defender seus interesses e valores. A experiência de religião civil no império foi útil para a Igreja emprestar ao Estado seu aparelhamento simbólico para auxiliar a construção da legitimidade da República e da identidade nacional. Esses préstimos foram úteis para uma política que acontecia sem o envolvimento dos subalternos da sociedade em seus movimentos. O Estado republicano não tinha povo, a Igreja Católica convenceu-o que ela o possuía.

Foram organizadas associações diversas segundo o espírito militante, como a revista "A Ordem", a "Liga Eleitoral Católica" e os movimentos da "Ação Católica". Dentre os líderes desse catolicismo destacamos o Cardeal Dom Sebastião Leme; o Arcebispo Dom Antônio Cabral; Jackson de Figueiredo, Alceu Amoroso Lima e Padre Júlio Maria. Uma das mais notáveis atividades políticas do catolicismo brasileiro desse período aconteceu por meio da operosidade do cardeal Dom Sebastião Leme. Em sua carta pastoral de 1916 ele declarou que o país era católico em sua mentalidade. No entanto, os católicos agiam pouco nos espaços públicos e políticos. No governo Vargas, Dom Leme buscou organizar o catolicismo de modo a fazer o Estado compreender que a mentalidade do povo era católica e a hierarquia da igreja era a sua representante, a ponto de Vargas conferir à Igreja Católica a mesma importância que conferia às forças armadas.

A partir da década de 1950 a política de expressivos setores do catolicismo brasileiro passa por aquilo que Bresser-Pereira ${ }^{8}$ chama de descomprometimento. Eles se descomprometem com a manutenção da política de natureza oligárquica do país. A mentalidade do pós Segunda Guerra somada à experiência democrática pela qual passava a nação a partir do final do Estado Novo, além de outros motivos, marcaram um importante ponto de inflexão nesse novo modo de pensar a organização política da sociedade. As experiências dos bispos do nordeste; Juventude Universitária Católica; Juventude Estudantil Católica; Juventude Operária Católica; Movimento de Educação de Base; Movimento Brasil, Urgente dentre outros movimento e também pessoas como o bispo de Santo André, Dom Jorge Marcos Oliveira,

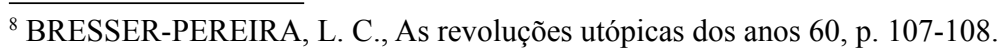


promoveram um ambiente intelectual e de fé que criou as condições para o surgimento da chamada esquerda católica. Ela principia a partir da segunda metade da década de 1950 e encontra organização melhor observável na primeira metade da década de 1960 quando foi interrompida pelo golpe de Estado civil-militar de 1964.

Essa novidade no catolicismo brasileiro é marcada por três eixos, a saber: a consciência histórica e a consciência da história; a fidelidade à grande tradição; e a revolução cristã. Esses três eixos marcaram a organização dos setores de esquerda do catolicismo alcançando a Teologia da Libertação. A consciência histórica e da história seria um produto da compreensão da condição histórica de Jesus Cristo. Por ela, esses cristãos elaboram um sentimento religioso fora da evasão histórica. O Filho de Deus não é um mero parêntese de bondade manifesto por Deus ao ser humano. O Criador não acompanha a história de longe. Ele participa dela e nela apresenta a Sua salvação como um processo de libertação concreta, que principia na libertação de todas as formas da antivida, tais como: exploração, injustiças, fome e etc.

Segundo o dominicano Thommas Cardonel, ${ }^{9}$ Jesus Cristo é a tradução na história do princípio ontológico do universo. O cristianismo trata da radical emancipação que se realiza a partir da história onde Deus e o humano mantêm uma relação de mútua afirmação. A história é o ambiente da divinização do humano. É o lugar onde Deus se faz humano para que o humano se divinize e se salve.

A história deve ser interpelada pelo cristão segundo os valores permanentes do cristianismo que não apresenta uma proposta de evasão e tampouco de ideal histórico porque ele nunca se degrada numa ideologia. É uma consciência histórica cuja originalidade se traduz nas "razões últimas do prodigioso dinamismo histórico que sua aparição deflagrou no mundo ocidental". ${ }^{10}$ A consciência do cristão reside na fé na presença de Deus no íntimo da trama histórica. Ele se manifesta e participa de sua trama, assumindo-a e apontando para a consumação final dos tempos. Contrapondo-se a enfoques individualistas e ultra-espiritualizados, afirma-se a consciência de que "os seres humanos são seres sociais e, como seres sociais, seres naturais. Por esta razão, não basta exprimir a esperança escatológica unicamente com o símbolo da vida eterna". ${ }^{11}$

\footnotetext{
${ }^{9}$ CARDONNEL, T., Deus não é mentiroso como certa paz social, p. 19-51.

${ }^{10}$ VAZ, H., Consciência cristã e responsabilidade histórica, p. 71.

${ }^{11}$ MOLTMANN, J., A vinda de Deus, p. 147.
} 
A fidelidade à grande tradição que se constitui o catolicismo é outro elemento constitutivo da esquerda católica que também podemos chamar de catolicismo da libertação ou social. Ele não se compreende como ruptura e reivindica diante de seus detratores a sua completa pertença ao magistério papal. O catolicismo é uma das grandes tradições do Ocidente. Esses cristãos se inserem na igreja em seu percurso histórico e sacramental na história reconhecendo a autoridade máxima do papa. $\mathrm{Na}$ esquerda católica, as mediações com o marxismo aconteceram sem causar rupturas com o cristianismo. Elas apoiaram as interpretações da realidade empírica sem assumir o seu materialismo. A compreensão marxista do desenvolvimento econômico foi entendido como um edifício à parte de seu ateísmo.

O magistério papal expresso na questão social, iniciada com a encíclica Rerum Novarum de Leão XIII, é o grande ambiente no qual esses católicos inserem suas asserções sobre a realidade social, política e econômica. Reivindicam-nas como documentos basilares do cristão no mundo. A partir da segunda metade do século $\mathrm{XX}$, os ensinamentos de Santo Tomás de Aquino foram tomados como mediadores entre os cristãos e a realidade social e econômica. Frei Carlos Josaphat foi um dos principais responsáveis desse movimento intelectual. Suas proposituras foram organizadas no livro Evangelho e revolução social cuja primeira edição aconteceu no ano de $1962 .{ }^{12}$ Trata-se de obra seminal para o pensamento de esquerda ou libertador do catolicismo brasileiro.

Por sua vez, o tema da revolução cristã no Brasil inicia na primeira metade da década de 1960 e é parte de um macro ambiente onde a revolução era a grande palavra-força. A experiência da revolução cubana foi adequadamente descrita por Sartre como um furacão. ${ }^{13}$ Mais do que conceitos, a metáfora do irresistível fenômeno da natureza era mais adequada para fazer compreender a força que a revolução possuía nas mentalidades naquele momento. A revolução cubana aparecia como um sinal da chegada do futuro almejado (em ruptura com as desigualdades sociais e econômicas). O carisma da palavra revolução era de tal ordem intenso e legitimador que até o movimento contrarrevolucionário do golpe de 1964 foi chamado de revolução pelos seus promotores e defensores.

Na década de 1960 um mundo inteiro parecia ruir diante dos olhos, principalmente dos jovens inebriados pelos mitos Che Guevara e Camilo

\footnotetext{
${ }^{12}$ JOSAPHAT, C., Evangelho e Revolução Social.

${ }^{13}$ SARTRE, J. P., Furacão sobre Cuba.
} 
Torres. Não era apenas na economia que as chamadas velhas estruturas pareciam ruir. O plano da cultura também passou pela diluição do momento que parecia fazer, efetivamente, tudo que era sólido se desfazer no ar. Valem os exemplos dos comportamentos da juventude, a revolução sexual, a música, o cinema, a poesia dentre outros.

Os setores de esquerda do catolicismo compreendiam que a revolução constituía-se em morte e ressurgimento de estruturas e mentalidades novas e historicamente situadas. Ela existe de maneira forte na matriz cristã que lida com a ideia da ressurreição que se traduz na superação da morte na direção de uma realidade nova situada no Absoluto. A revolução, para esses setores, encontrava uma correspondência no ato ressurreição. Ambas superam uma dada realidade e inauguram outra que supera em tudo a anterior. $\mathrm{O}$ ato revolucionário é mais propriamente cristão do que marxista, para esses católicos. Cumpria-lhes, portanto, devolvê-lo ao seu lugar original.

No caso brasileiro, o golpe de 1964 interrompeu o processo de rupturas políticas e econômicas que se acreditava culminar com a idealizada e imprecisa revolução presente nas mentalidades. O catolicismo deixa o tema da revolução e passa em fins da década de 1960 a adotar a libertação como eixo teórico e prático de sua pastoral. ${ }^{14}$

\section{Puebla e a militância dos jovens da PJMP}

A descrição do contexto com o qual o catolicismo e a juventude da década de 1960 “dialogam” é fundamental para que tenhamos uma compreensão adequada do objeto de pesquisa deste artigo. Tal contexto ajuda a entender a dinâmica própria de setores do catolicismo brasileiro de organizar seus modos de tratar a questão social. Esses jovens católicos elaboraram uma vaga ideia de revolução na direção de um socialismo igualmente vago e impreciso. A recusa ao capitalismo e a suas consequências ocupavam mais suas elaborações do que propriamente uma ideia de socialismo. Seguiam admirando a experiência cubana, o sandinismo, Che Guevara, Fidel Castro etc.

Operavam a ideia da necessária consciência histórica e, também, do "espírito do tempo". Seria uma insuportável alienação a perda do momento histórico, ou, como convém ao mineiro: perder o "trem da história". Essa perspectiva se associa às ideias de juventude definidas pela sua abertura

${ }^{14}$ GUTIÉRREZ, G., Teologia da libertação. 
ao futuro. A militância política expressava uma ruptura com as práticas de evasão da história do catolicismo ibérico que a compreendia como um vale de lágrimas, lugar de degredo. Podemos dizer que esses setores progressistas da juventude católica concordariam com a seguinte afirmação de Moltmann: "se a esperança cristã for reduzida à salvação da alma num Céu além da morte, ela perde a sua força renovadora da vida e transformadora do mundo e consomese num anseio gnóstico de redenção do vale de lágrimas deste mundo". ${ }^{15}$ Eles estavam organizados nas estruturas (arqui)diocesanas e se compreendiam inseridos na tradição bíblica. Interpretavam a Bíblia a partir das experiências vividas e interpretavam as experiências vividas a partir da Bíblia. As comunidades dos primeiros cristãos eram o modelo de sociedade, fornecia o exemplo a ser reproduzido, como na "comunhão fraterna" e na "fração do pão" (At 2,42). A ênfase nos aspectos coletivos alerta que "ninguém tem ou recebe vida eterna apenas para si sem a comunhão com outras pessoas e sem a comunhão com toda a criação". ${ }^{16}$ Tal esperança levaria ao envolvimento na busca da solução dos problemas que afligem os seres humanos e não mais ao sectarismo e à apatia sociopolítica.

A PJMP iniciou seu percurso histórico e eclesial nas periferias de Recife organizadas, principalmente, por ex-membros da Juventude Operária Católica - JOC - desarticulada pela Ditadura Civil Militar. Sob a liderança de Dom Hélder Câmara, apresentavam a prática da fé cristã estruturada a partir do lugar social dos jovens empobrecidos moradores das periferias urbanas. Essa experiência pastoral organizou-se em diversas regiões do Brasil de maneira relevante no interno do catolicismo e na sociedade civil. Muitos de seus membros vieram a integrar setores organizados da comunidade política como partidos, sindicatos e associações de bairros.

A experiência da Pastoral da Juventude do Meio Popular se iniciou em Minas Gerais em meados da década de 1980. O primeiro encontro registrado aconteceu na cidade de João Monlevade e de lá passou a existir em outras cidades do Vale do Aço mineiro, como Ipatinga e Coronel Fabriciano, e também na região industrial da grande Belo Horizonte. Naquele momento, ficou claro para os jovens que aquela nova experiência diferenciava-se pela militância em relação aos grupos genéricos paroquiais. A militância em diversos organismos da sociedade, tais como: partidos políticos, sindicatos, movimento estudantil e

\footnotetext{
${ }^{15}$ MOLTMANN, J., A vinda de Deus, p. 15.

${ }^{16}$ MOLTMANN, J., A vinda de Deus, p. 147.
} 
associações de bairro, era o objeto de sentido que dava coesão e identidade ao grupo. A motivação da fé traduzia-se nas atividades fora da instituição Igreja Católica, segundo o espírito da Ação Católica. A política era percebida como critério salvífico por meio do compromisso da fé que impõe a necessária ação pela transformação da sociedade. Por meio da política poder-se-ia praticar de modo perfeito a caridade cristã, porque ela questionava e permitia a ação nas estruturas produtoras de injustiças e desigualdades contrárias ao Reino de Deus.

Houve uma afinidade entre as propostas dessa pastoral e o ambiente efervescente de emergência dos movimentos sociais, oposições sindicais e diversas organizações que agiam a favor das eleições diretas que marcaram aquele período final da ditadura militar. Aquilo que eles sentiam sem muita elaboração foi se organizando em reflexões a partir da experiência da PJMP. Eles interiorizaram o tema da luta de classes como elemento definidor da ação e de identidade da pastoral. O denominativo meio popular registrava para eles o lugar de classe no qual viviam. Consideravam contraditória a hegemonização da fé de integrantes de classes sociais e econômicas diferentes. Esses lugares marcam hermenêticas distintas.

Os documentos produzidos por esses militantes fundavam-se largamente no capítulo II "Opção preferencial pelos jovens" do texto oficial da conferência do episcopado latino-americano realizado na cidade de Puebla de Los Angeles, México, no ano de 1979. A síntese publicada pelo episcopado e os documentos produzidos pelos jovens concordavam com a ideia de que a juventude não é definida apenas pela idade cronológica, mas como uma etapa de transição que se define como uma atitude diante da vida.

Esses jovens assimilavam essa compreensão, mas a ultrapassavam. Seria difícil para eles recusarem as compreensões do episcopado porque concordavam com seu tom existencial, ou seja, juventude como dínamo da cultura; liminar e transformadora. No entanto, eles aumentaram a dose das questões sociais comparativamente aos bispos. Essa atitude pode ser definida por algumas palavras-chave que encontramos tanto no texto final quanto no material produzido pelos jovens e nas entrevistas que realizamos. Selecionamos as seguintes palavras como modo de dar uma medida da mentalidade sobre essa condição: inconformismo, questionar, espírito de aventura, capacidade criadora, transformação, esperança, liberdade, alegria, felicidade, autenticidade, simplicidade, rebeldia, dinamismo, força.

Puebla coloca para a juventude o papel do protagonismo disciplinado. Reconhecenelaopapeldaquelesqueseguemadiantenahistória,transformando-a 
como se fosse a presença do futuro no presente, uma antecipação do que virá. Desse modo, a ideia produzida sobre o ser jovem acompanha a ideia geral dos demais grandes movimentos de juventude do século XX. No entanto, esse papel deveria ser disciplinado para que não ocorressem novamente as experiências radicais e revolucionárias da juventude da década de 1960, que a Conferência de Medellín via diante de si no emblemático ano de 1968. Embora reconheça a situação do empobrecimento, Puebla deu um peso mais existencial e menos político para o problema dos jovens.

Essa pastoral de militantes envolveu-se nas questões políticas e econômicas de maneira intensa. A militância acontecia em movimentos sociais e políticos diversos como partidos, sindicatos e associações de bairro. Vale pensar em algumas outras palavras-chave que selecionamos sobre esse tema: bandeira, luta, mundo novo, força, coragem, classe, engajamento, sindicato, partidos, direitos e política partidária. Embora presente, o tema da revolução não aparecia como na década de 1960. Ele foi substituído por libertação.

Embora suas proposições ultrapassassem as conclusões do episcopado, os jovens da PJMP concordavam com os bispos em diversos pontos. Assentem que os maiores riscos diziam respeito ao mundo do trabalho. Os jovens trabalhavam como adultos e, ao mesmo tempo, não tinham certeza de empregos no futuro. Eram vítimas do trabalho precário e da falta de perspectiva. Esse fato despertava o temor de que a juventude não conseguisse viver as experiências próprias desse momento da vida. Sem perspectiva, abertura para o futuro, a condição do ser jovem é golpeada de morte. E com ela a capacidade da sociedade se dinamificar. A causa seria a sobrevivência não garantida. O jovem se via obrigado a direcionar todo o seu esforço, todas as suas energias, na garantia da manutenção material básica de sua vida e de sua família, encerrando-se no presente.

Nem todos os jovens latino-americanos experimentavam essa realidade. Uma minoria deles não estava sob este imperativo. Esse gradiente de experiências de vida, variáveis segundo o lugar social, que determinam trajetórias e concepções de mundo radicalmente diferentes, faz os membros da PJMP se afirmarem como uma pastoral do meio popular. Ou seja, uma pastoral de jovens que experienciam a fé a partir de um lugar social específico: nas periferias das cidades, na cultura e no mundo do trabalho. Compreendiam ser impossível ter a mesma experiência de fé a partir de lugares com diferenças tão marcantes em dimensões estruturantes do estar humano no mundo.

O interesse fundamental dos jovens das periferias é a superação de sua 
condição de empobrecidos e de discriminados. Em atenção a esse interesse fundamental os membros dessa pastoral de militantes buscavam, através da mediação do político, da práxis política, a construção de um mundo de paz, justiça e amor referido no documento de Puebla. Efetivamente eles buscaram, no entanto não foram plenamente atendidos na procura.

O texto da "Opção preferencial pelos pobres" foi largamente usado pelos jovens da PJMP, embora tenhamos identificado que o acompanhavam apenas parcialmente. $\mathrm{O}$ documento não tratava de maneira clara e decidida a questão dos pobres. Existem parágrafos que entram em desacordo diante do tema. Revelam a existência de grupos opostos na formulação do problema e dos encaminhamentos de sua compreensão e superação.

Quando trata do serviço ao irmão pobre, o documento final dilui o problema da pobreza. Ao chamá-lo de irmão reduz a densidade social, política e econômica do pobre, da pessoa que vive a realidade objetiva. Assemelha-se ao que Hannah Arendt ${ }^{17}$ disse sobre a dificuldade que Santo Agostinho cria para a política quando define que a sociedade deve se estruturar na relação entre irmãos. Essa relação de natureza familiar de filhos do mesmo Pai não possui natureza política. A pobreza como condição das pessoas que estão fora do universo de consumo do alimento, moradia, ausência de escolas, torna-se rarefeita numa linguagem quase metafórica. Nesse momento, o texto propõe que, ao se aproximar do pobre para acompanhá-lo e servi-lo, deve-se fazer segundo os ensinamentos de Cristo ao se fazer irmão e pobre como o humano. Esse sentido da pobreza de Cristo não tem o mesmo sentido da pobreza como pensavam e viviam os jovens de nossa pesquisa.

A pobreza das pessoas que se impõe de maneira incontornável trata da fome do corpo, do estômago, da falta de habitação etc. Nesse momento, o texto não trata o pobre como sujeito de sua própria emancipação. É objeto de acompanhamento e serviço dos que não são pobres. Esse modo de lidar com os empobrecidos coloca-os como objeto de indulgência. Sua existência é boa para os ricos se salvarem.

Ao aproximar-nos do pobre para acompanhá-lo e servi-lo, fazemos o que Cristo nos ensinou, quando se fez irmão nosso, pobre como nós. Por isso o serviço dos pobres é medida privilegiada, embora não exclusiva, de nosso seguimento de Cristo. ${ }^{18}$

\footnotetext{
${ }^{17}$ ARENDT, H., A promessa da política.

${ }^{18}$ DP 1145.
} 
Por outro lado, quando trata das linhas pastorais, o documento adota orientações que partem de matrizes compreensivas diferentes da parte que lhe antecede, sobre a situação do pobre, e da natureza da pobreza. Num momento, ela é tratada como virtude do próprio Cristo no parágrafo 1145. Noutro momento, é condenada por ser resultado escandaloso dos desequilíbrios econômicos.

Esta opção, exigida pela escandalosa realidade dos desequilíbrios econômicos da América Latina, deve levar a estabelecer uma convivência humana digna e a construir uma sociedade justa e livre. ${ }^{19}$

Passa-se a que a condição do pobre deve ser superada porque se trata da condição daqueles que têm fome. Refere-se à pobreza produzida pela economia e sustentada pela política. As estruturas sociais e as mentalidades individualistas que legitimam essas estruturas devem ser superadas. Essa pobreza de natureza econômica impede uma vida humana digna e feliz e deve ser rejeitada.

A necessária mudança das estruturas sociais, políticas e econômicas injustas não será verdadeira e plena se não for acompanhada pela mudança de mentalidade pessoal e coletiva com respeito ao ideal duma vida humana digna e feliz. ${ }^{20}[\ldots]$ A exigência evangélica da pobreza, como solidariedade com o pobre e como rejeição da situação em que vive a maioria do Continente, liberta o pobre de ser individualista em sua vida e ser atraído e seduzido pelos falsos ideais duma sociedade de consumo. Da mesma forma, o testemunho duma Igreja pobre pode evangelizar os ricos, que têm o coração apegado às riquezas, convertendo-os e libertando-os desta escravidão e de seu egoísmo. ${ }^{21}$

Devemos notar a eficiente sutileza do texto que apresenta a expressão "Opção preferencial pelos pobres". O adjetivo "preferencial" reduz a densidade do substantivo "opção". Setores do episcopado temiam que a "Opção pelos pobres" pudesse levar os católicos à radicalização. O grupo que fez a proposta dessa expressão temia o retorno das experiências da década de 1960, a Revolução Cubana e a Guerra Fria. Compreendiam que essa

\footnotetext{
${ }^{19}$ DP 1154.

${ }^{20}$ DP 1155.

${ }^{21}$ DP 1156.
} 
expressão poderia fortalecer a opção pelo marxismo que já seduzia muitos católicos. O problema que se apresentou foi: como não eleger os pobres como os privilegiados? A saída foi enfraquecer o substantivo com o uso do adjetivo.

Os jovens da PJMP se associaram ao ambiente de proposições do texto final da conferência quando ele trata da pobreza como produto da economia. Ela é algo injustificável quando há uma capacidade de produção de riquezas nunca antes alcançada pela humanidade. Compreendiam ser um pecado estrutural a dupla produção de riqueza e de pobreza do capitalismo. A ideia sobre esse sistema é que ele produz a riqueza e ao mesmo tempo a pobreza, privilegiados e excluídos, proprietários e explorados.

Esses jovens vivem em situação de vulnerabilidade social, moradores das periferias e, na ampla maioria, filhos de migrantes que saíram de diversas regiões rurais em busca de melhores condições de vida nas regiões industriais. Seus pais não tinham qualificação profissional e não conseguiam empregos formais na grande maioria das vezes. A pobreza para eles não era uma metáfora. Também estavam distantes da perspectiva medieval dos pauperes Christi, os "pobres de Cristo", eleitos por Deus, "homens que renunciaram aos bens deste mundo para alcançar com mais segurança o reino dos céus". ${ }^{22}$ Não era, em hipótese alguma, o caso. Eles não renunciaram aos bens. $\mathrm{O}$ acesso aos bens básicos à sobrevivência era-lhes negado por uma conjuntura socioeconômica perversa, para não dizer "satânica". Acompanhavam as orientações do texto que propunha a mudança estrutural da sociedade. Não compreendiam a "virtude da pobreza" que produz condições de vida onde a moradia é insuficiente para abrigar toda a família, por exemplo.

Quando faltam alimento, remédio e outros itens básicos à sobrevivência, a ideia sobre a pobreza de Jesus Cristo ganha um novo registro hermenêutico. Eles O compreendiam como companheiro. Ele alimentava o espírito e iluminava o caminho, metáfora da história, lugar onde ocorre o percurso de lutas pela garantia de vida e pela mudança de estruturas. Eles seguem, portanto, a tradição que é representada pelo episcopado.

O partido político aparecia como instrumento para as mudanças da estrutura. Compreendiam que a política era espaço diferente do eclesial. Possuía riscos novos, mas era necessário assumi-los. As mediações das instituições políticas eram vistas com um misto de desconfiança e encantamento. Elas são espaços de poder. Esse dado encantou os jovens moradores das periferias

${ }^{22}$ GUREVITCH, A. I., A “visão de mundo” do homem da Idade Média, p. 26. 
politicas, econômicas e sociais. O Partido dos Trabalhadores (PT) - enquanto existiu como partido de massas - ofereceu condições para que eles pudessem experimentar os espaços da disputa do poder político.

Importante observar que partidos comunistas não conseguiriam atender essa demanda embora pudessem ser considerados - em tese - como aqueles que se ocupam das mudanças estruturais mais intensas e profundas. Os jovens do nosso estudo estavam inseridos na cultura política e mentalidade dos movimentos sociais de ampla participação, também chamados de movimentos de massas. O partido político que melhor pode comportar a ampla participação foi o Partido dos Trabalhadores. O partido comunista, por exemplo, não conseguiu atender esse momento histórico por causa de sua estrutura leninista de partido de quadros dirigentes dos movimentos situados fora de sua estrutura. Ela queria ocupar o partido político em sua estrutura interna, influir em seu funcionamento, propor e conduzir debates. Essa condição de massas do PT foi o resultado da demanda política de um momento de ampla organização da sociedade civil brasileira em torno da redemocratização.

\section{Conclusão}

Iniciamos este texto falando do otimismo, herdeiro da "ideologia do progresso" oitocentista que ainda ecoava no século XX e elegia a juventude como a perpetuadora de seu legado. Entretanto, principalmente após as duas grandes guerras e as consequências funestas da exploração da natureza pelo homem, o otimismo se reverteu em uma expectativa catastrófica e o "sonho quiliástico da "era moderna" 23 tornou-se pesadelo. De acordo com Hartog, especialmente a partir da década de 1980, essa preponderância do futuro começou a ser questionada. Como que despertada de um "sonho colorido" de bem-aventurança terrena, a humanidade se viu obrigada a repensar suas crenças. O futuro, anteriormente imaginado como sempre melhor do que o presente, tornou-se imprevisível graças às "ambiguidades do progresso", que criava novas possibilidades, mas, também, novos riscos. "O presente encontrou-se marcado pela experiência da crise do futuro, com suas dúvidas sobre o progresso e um porvir percebido como ameaça". ${ }^{24} \mathrm{O}$ futuro voltou a

\footnotetext{
${ }^{23}$ MOLTMANN, J., A vinda de Deus, p. 211.

${ }^{24}$ HARTOG F., Regimes de historicidade, p. 250.
} 
ser desconhecido. E, sendo desconhecido, aberto a diferentes interpretações e expectativas.

Os temores em relação ao final repentino que poderia se tornar realidade com o "holocausto nuclear" ou o apocalipse a "conta-gotas" da destruição do meio ambiente - pela exploração predatória dos recursos naturais - lançavam sucessivos baldes de água fria no otimismo de iluministas tardios. Entretanto, a juventude ainda era vista como a esperança de um futuro melhor. Os jovens teriam o "poder" de romper com o terror de um futuro pós-apocalíptico (retratado em filmes como Mad Max) que se avizinhava. Um hit musical do início da década de 1980 dizia que "It's so hard to get old without a cause / I don't want to perish like a fading horse / Youth's like diamonds in the sun / And diamonds are forever / Forever young / I want to be forever young". ${ }^{25}$

Os jovens da Pastoral da Juventude do Meio Popular viviam nesse contexto entre as expectativas otimistas em relação ao protagonismo da juventude no destino da humanidade e questionamentos em relação às estruturas malignas que colocavam as expectativas em relação a um futuro de justiça e fraternidade em cheque. Herdeiros das proposições das esquerdas católicas formuladas na década de 1960, não compreendiam a história como um vale de lágrimas. Não pensavam estratégias de evasão da história. Ela não era lugar para se fugir. Nela principia o Reino de Deus.

Inseriam-se na adesão à tradição do catolicismo. Situavam-se dentro da estrutura diocesana. Acompanharam as asserções da Conferência de Puebla filtrando-as a partir de suas realidades particulares de jovens empobrecidos. A condição de militantes nas diversas esferas da sociedade civil organizada no momento de emergência dos movimentos sociais a partir das décadas de 1970 e 80 os fez assumir a interpretação da realidade a partir de críticas ao capitalismo com uma imprecisa proposta de socialismo. Seus questionamentos ecoavam um espírito de questionamento das estruturas vigentes e da negação de perspectivas religiosas deterministas e de passividade política característicos de uma juventude comprometida com uma interpretação do cristianismo e do texto bíblico que amparava um discurso de condenação às estruturas sociais e econômicas malignas desenvolvidas por um capitalismo insensível aos dramas dos mais pobres.

\footnotetext{
25 Música Forever Young do conjunto alemão Alphaville: ALPHAVILLE. Forever Young. In. ALPHAVILLE. Forever Young. Manaus: WEA Music, 1984. 1 CD (43 min 12 s). Faixa 6 (3 min $47 \mathrm{~s})$.
} 


\section{Referências bibliográficas}

ALPHAVILLE. Forever Young. In: ALPHAVILLE. Forever Young. Manaus: WEA Music, 1984. 1 CD (43 min $12 \mathrm{~s}$ ). Faixa 6 (3 min $47 \mathrm{~s}$ ).

ARENDT, H. A promessa da política. Rio de Janeiro: DIFEL, 2010.

AZEVEDO, T. A religião Civil Brasileira: um instrumento político. Petrópolis: Vozes, 1981.

BÍBLIA Pastoral. 15a impressão. São Paulo: Paulus, 2003.

BRESSER-PEREIRA, L. C. As revoluções utópicas dos anos 60: a revolução estudantil e a revolução política na Igreja. São Paulo: Editora 34, 2006.

CARDONNEL, T. Deus não é mentiroso como certa paz social. In: CARDONNEL, T.; VAZ, H.; SOUZA, H. J. Cristianismo hoje. Rio de Janeiro: Editora Universitária, 1962. p. 19-51.

CELAM. Conclusões da III Conferência Geral do Episcopado Latinoamericano. Evangelização no presente e no futuro da América Latina. São Paulo: Paulinas, 1979.

GUREVITCH, A. I. A "visão de mundo" do homem da Idade Média. In: GUREVITCH, A. I. As categorias da cultura medieval. Lisboa: Caminho, 1991. p. 13-40

GUTIÉRREZ, G. Teologia da libertação. Petrópolis: Vozes, 1979.

JOSAPHAT, C. Evangelho e Revolução Social. São Paulo, Loyola, 1962.

HARTOG, F. Regimes de historicidade: presentismo e experiências no tempo. Belo Horizonte: Autêntica, 2013.

KOSELLECK, R. Futuro passado: contribuição à semântica dos tempos históricos. Rio de Janeiro: Contraponto / Ed. PUC-Rio, 2006.

MEIRELES, C. Poesias completas: Rio de Janeiro: Civilização Brasileira, 1974. v. 5: Romanceiro da Inconfidência; crônica trovada da cidade de Sam Sebastian.

MOLTMANN, J. A vinda de Deus: escatologia cristã. São Leopoldo: Unisinos, 2003.

SARTRE, J. P. Furacão sobre Cuba. Rio de Janeiro: Editora do Autor, 1986. VAZ, H. Consciência cristã e responsabilidade histórica. In: CARDONNEL, 
T.; VAZ, H.; SOUZA, H. J. Cristianismo hoje. Rio de Janeiro: Editora Universitária, 1962.

VEYNE, P. Quando nosso mundo se tornou cristão (312-394). São Paulo: Civilização Brasileira, 2011.

Wellington Teodoro da Silva Doutor em Ciências da Religião pela Universidade Federal de Juiz de Fora Docente do Departamento de Ciências da Religião da Pontifícia Universidade Católica de Minas Gerais Docente convidado na Universidade de Havana (Cuba) Belo Horizonte / MG - Brasil E-mail: wteodoro@pucminas.br

Daniel Rocha

Doutor em História pela Universidade Federal de Minas Gerais

Docente de Teologia do Instituto Santo Tomás de Aquino Docente Colaborador do Programa de Pós-Graduação em Ciências da Religião da Pontifícia Universidade Católica de Minas Gerais Belo Horizonte / MG - Brasil E-mail: danielrochabh@yahoo.com.br

Recebido em: $13 / 08 / 18$

Aprovado em: 27/02/19 